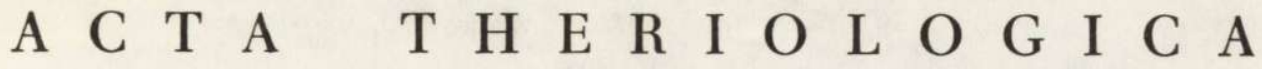 \\ VOL. $19,16: 247-257$. \\ BIAEOWIEŻA \\ September, 1974
}

\author{
Krystyna A D A M C Z Y K \& Wiera W A L K O W A
}

\section{Estimating the Number of Newborn Animals in Enclosed Populations of Laboratory Mice *}

[With 1 Table \& 6 Figs.]

\begin{abstract}
Eighty three populations of laboratory mice were studied over a 5 month period. The size of the populations varied between 20 and 220 and the numbers of animals in each population was maintained at the original level throughout by the removal of selected individuals where necessary. Estimates of the numbers of newborn mice were obtained in three ways: (1) by daily recording of the number of newborn mice, (2) by adding to the above an estimate of the number of mice which died in the period between birth and the first record, (3) by multiplying the number of pregnancies by the average litter size. The third method gives the most reliable estimate of the number born, the other two give a markedly lower figure. Examination of the females once every two weeks made it possible to record $81.3 \pm 2.7 \%$ of pregnancies whilst twice weekly examination made it possible to detect all pregnancies. The average litter size, as revealed by dissection, was $7.5 \pm 0.2$ individuals in the study populations.
\end{abstract}

\section{INTRODUCTION}

In studies of enclosed populations of rodents under laboratory conditions the estimation of the number of young born presents considerable difficulties. Usually, newborn animals are counted directly. Many researchers counted newborn animals at intervals of 7 to 14 days (Christian, 1956; Crow cr of t \& R owe 1957, 1958; S o u thwick, 1955a, b; Strecker \& E'mlen, 1953, etc.), their primary intention being not so much to obtain the absolute number of animals born as to estimate the number of young individuals forming the birth rate index. This may be justified by the desire to reduce to a minimum any possible adverse effect due to the experimenter's interference with the population. Other researchers counted newborn mice daily (B e il harz, 1968; Louch, 1956; Petrusewicz, 1957, 1960, 1963; Vessey, 1967; Walkowa \& Petrusewicz, 1967; Walkowa, 1971 etc.). Both

* Praca została wykonana w ramach problemu węzłowego 09.1.7, koordynowanego przez Instytut Ekologii Polskiej Akademii Nauk. 
assessments may be under-estimated by the number of young which died between time of birth and their first registration.

The number of newborn mice can also be indirectly estimated if the number of pregnancies ending in birth is known, and also the size of the average litter.

The purpose of this study was to compare estimates of the numbers of newborn animals in populations of white mice obtained by: (1) daily counts of the number of newborn mice, (2) supplementing the above number by an estimate of number of individuals which died during the period from birth to the first registration, (3) estimating the number of pregnancies ending in birth and the size of the average litter.

\section{METHODS}

Studies were made on 83 populations of albino laboratory mice (Mus musculus L in n a u s, 1755) kept in wooden cages under laboratory conditions for 5 months. The populations were set up with mice 2-4 months old, in a gradient of population size from 20 to 220 individuals. All the mice were individually marked. Water and food were supplied ad libitum.

The number of newborn mice, whether dead or alive, were recorded daily for each population, and the dead animals removed. Also, in order to assess mortality, the number of young animals whose birth had taken place on a given day and which survived until the following day was also noted.

In order to obtain information on the daily cycle of birth of the young and the survival of young mice from the time of their birth until their first registration, the number of young born in 18 of the study populations was recorded every two hours for a period of 5 days. These animals were marked by coloured spots on the coat and a count was kept of the number of individuals which survived from one observation to the next.

Each adult female was weighed every two weeks. Pregnancy was established on the basis of changes in body weight between successive weighings and the external appearance of the animals. An additional indication was the presence of a copulatory plug and blood in the vagina, which also permitted the estimation of how far pregnancy had advanced. In order to estimate the extent of the error made with the given frequency of assessment the examination of females was increased to twice a week in 15 of the 83 study populations.

Individuals born in the population which survived to the age of $4-6$ weeks were removed, leaving only a sufficient number to maintain a constant number of individuals in the basic stock.

On completion of the experiment all the females were dissected (1381 individuals, including 691 pregnant females) from 44 populations, in order to estimate the number of: (a) pregnant females, (b) live embryos and their size (measurements were made of one average-sized embryo only, chosen at random from each pregnant female), (c) resorbed embryos.

\section{COMPARISON OF THE DIFFERENT WAYS OF ESTIMATING THE NUMBER OF MICE BORN}

The numbers of mice born were estimated by totalling the number of newborn animals found by daily recordings of both live mice and also 
those which had died but were not eaten by the adults (first method).

A considerable number of newborn mice may die and be eaten between the time of birth and the first recording made. An attempt was made at assessing this number, calculating mortality per 24 hours for the whole study period for each population for this purpose. It was next assumed that the rate of loss of mice over a 24 -hour period is constant between the two first observations. Thus 12 hours after recording newborn mice their mortality forms half the value in percentage of the mortality found for the whole 24 hour period.

Using the recordings in which newborn mice were counted every two hours as a basis, it was found that births were evenly distributed over the 24 hour period (Fig. 1). It was therefore assumed on these grounds that, on an average, mice are born about 12 hours before their daily registration.

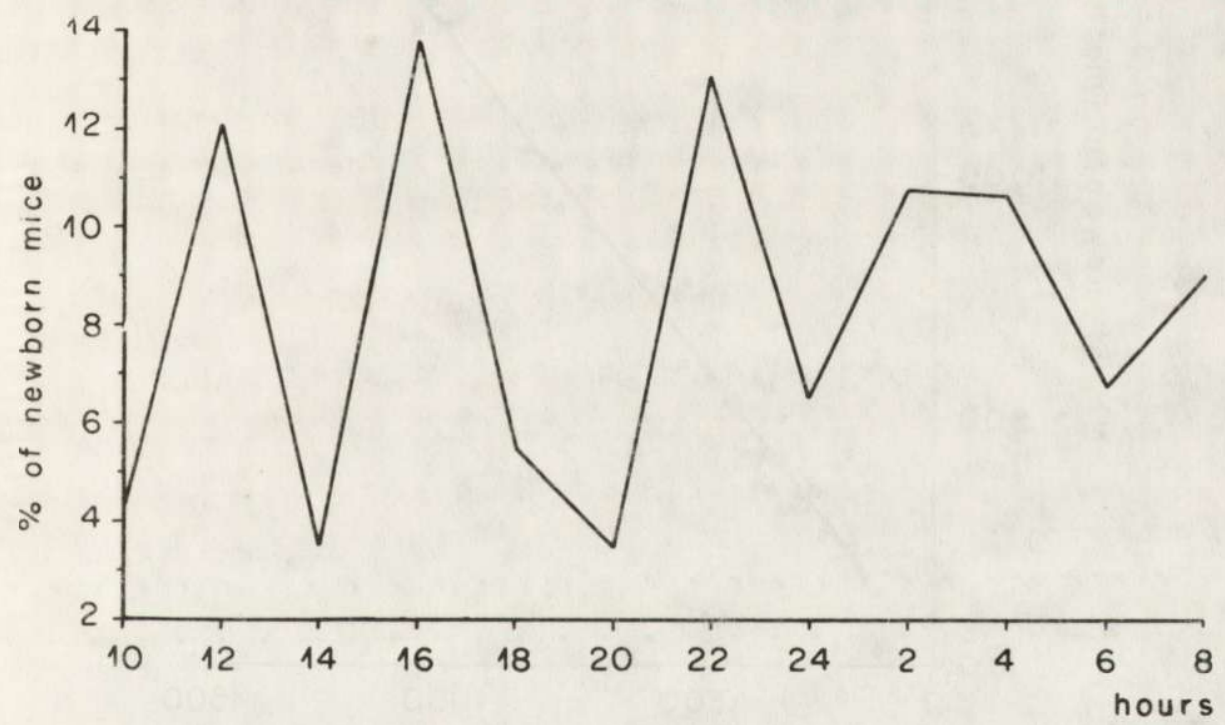

Fig. 1. Distribution of percentage of mice born during a 24-hour period. The number of 710 individuals born during a 5-day period was taken as $100 \%$.

When the record of the number of mice born is increased by the average number dying over half the 24-hour period, we obtain the number of newborn mice at the time of birth (second method). Comparison of these results with data obtained from daily recordings is illustrated in figure 2 , which shows that there is a straight line relationship between these two methods.

Accurate empirical checking of the number of mice born in the population is difficult on account of the labour involved and the 
disturbance caused by recording the newborn mice (their removal from the cage, marking etc.). Although these difficulties were fully realized an attempt was made at obtaining more exact data for a five-day study period using 18 populations, in which newborn mice were counted every two hours and the estimates obtained compared with estimates made once daily in these same populations and at the same time (Table 1). It was

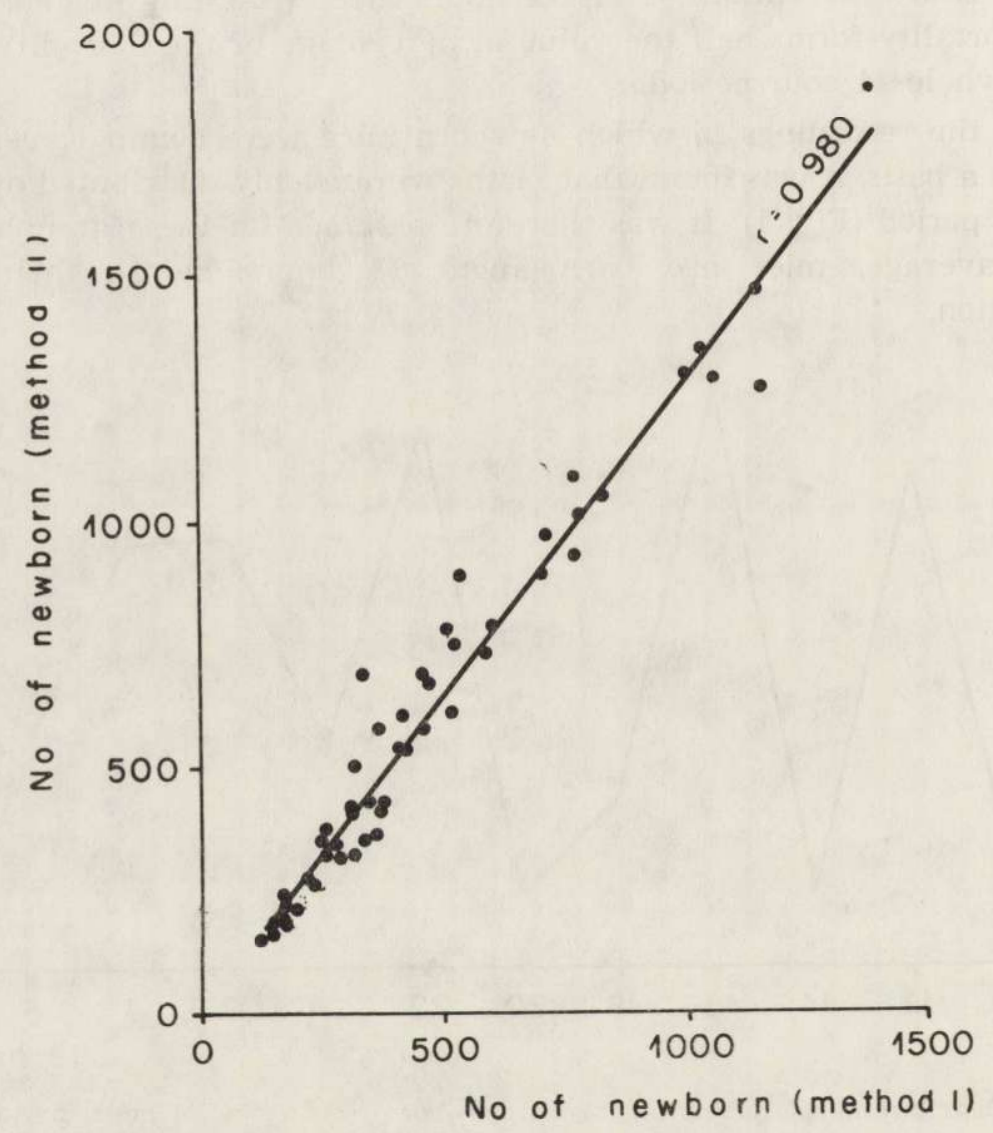

Fig. 2. Comparison of number of mice born estimated by daily recordings of newborn mice (method I) and increasing this estimate by the estimated number of newborn mice dying before being recorded (method II).

found that if the population is inspected once daily a large number of newborn mice are not recorded, particularly in very dense populations.

On the basis of these observations an analysis was made of the mortality of young mice during the first 24 hours of their life, at two-hour intervals, taking the number of all newborn animals as the basis for calculating percentages (Fig. 3). It was found that the 
distribution of mortality follows a curved line, as the largest number of individuals die within the first 12 hours of life. In addition the mortality of newb $=r n$ mice is distinctly smaller in less dense populations. If the mortality of newborn mice is always greater up to the 12th hour of life, not only for the five study days, then the method of estimating the number of mice born by means of daily registration with correction for mortality (assuming that it is of a straight line character) not only does not over-estimate but in fact underestimates the real value.

\section{Table 1}

Comparison of number of newborn mice estimated by two-hourly inspections and inspection made once daily. Data relate to 5 -day period.

\begin{tabular}{lrrrrrr}
\hline $\begin{array}{l}\text { No. of adult mice } \\
\text { in population }\end{array}$ & 20 & 60 & 100 & 150 & 220 & Total \\
\hline Every 2 hours & 74 & 240 & 253 & 209 & 85 & 851 \\
Once daily & 65 & 131 & 95 & 95 & 37 & 423 \\
Per cent & 88 & 55 & 37 & 45 & 43 & 49 \\
No. of population & 5 & 5 & 5 & 2 & 1 & 18 \\
\hline
\end{tabular}

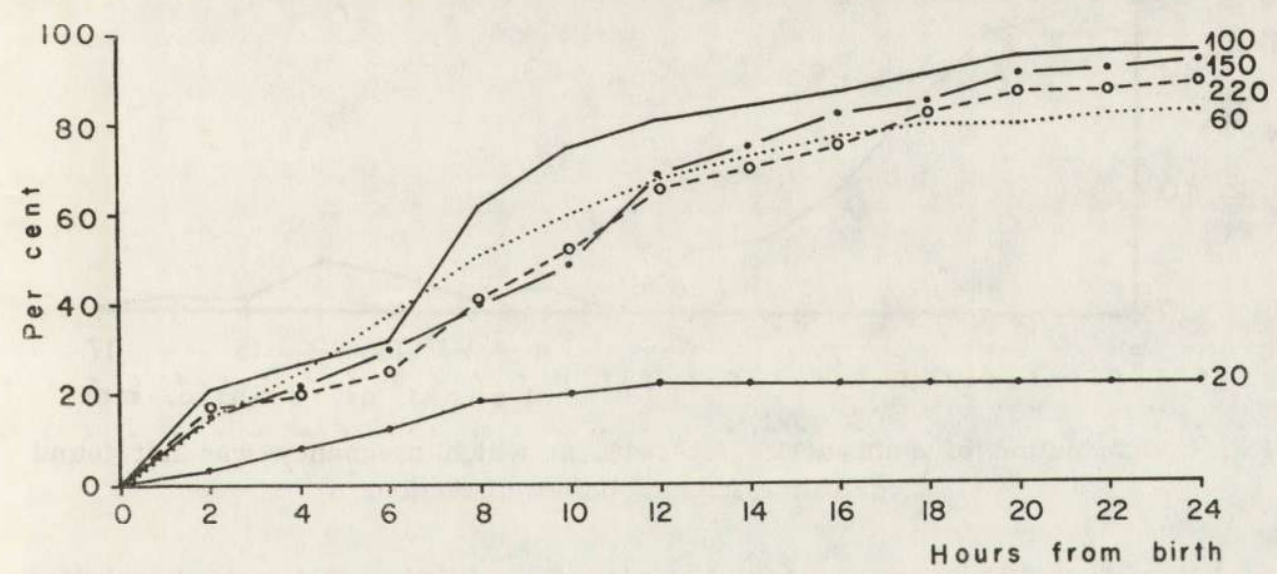

Fig. 3. Mortality among young mice during the first day of their life, in percentages of all newborn mice in the given group of population size $(20,60,100,150,220$ mice in a population).

The number of mice born may be obtained if the number of all pregnancies ending in birth is known, and also litter size.

Gestation lasted on an average for 19.6 days in laboratory mice (Myrcha, Ryszkowski \& Walkowa, 1969), but visually perceptible pregnancy only for a few days before the female gave birth. In the study population pregnancy was assessed in females every two 
weeks. Visual assessment of pregnancy may therefore be incorrect, in view of the impossibility of diagnosing the earlier stages of pregnancy. If more frequent inspections are made this increases the likelihood of encountering advanced pregnancy which can be recognized visually without difficulty.

Tests were made to assess how often females should be inspected in order to record all pregnancies, and for this purpose the size of the embryo was taken as an indicator of the stage pregnancy had reached. Before killing the animal for dissection it was examined visually to see whether it was pregnant, and the evaluation compared with the results of dissection. Embryos from $3 \mathrm{~mm}$ upwards were taken into consideration.

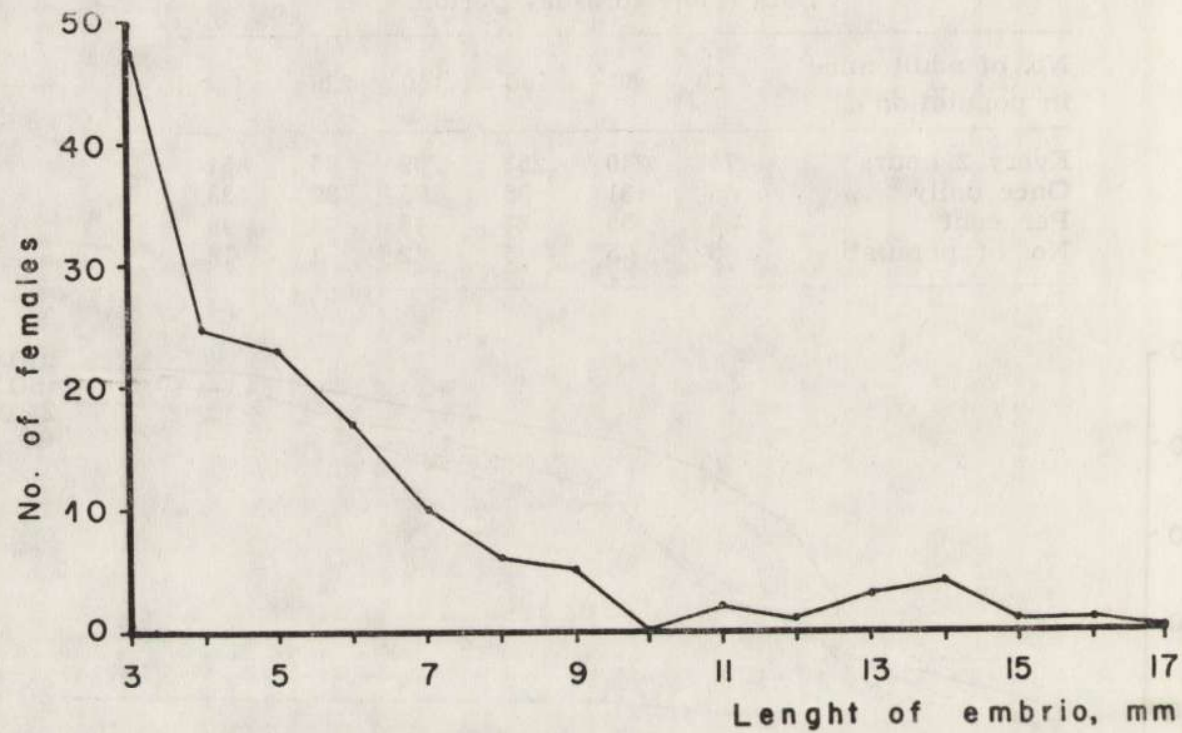

Fig. 4. Distribution of embryo size for cases in which pregnancy was not found in gestating females before dissection.

In 148 out of 691 pregnant females visual evaluation did not reveal the pregnancy shown by dissection. The distribution of the size of embryos was plotted for these cases (Fig. 4). It was calculated that $92 \%$ of the embryos did not exceed $9 \mathrm{~mm}$ in lenght, which is the size attained by the embryo of white mice of strain CFI-S on about the 13th day of gestation ( $\mathrm{R} \mathrm{ugh}, 1968)$ and the embryo of a wild house mouse kept in the laboratory on the 12-13 day of gestation (T heile r, 1972). This means that the greatest error was made in estimations when observations of mice were made at a period longer than 6 days before birth. The maximum length of an embryo in the case of the erroneous evaluation of pregnancy (only one such case was found out of the 33 embryos of 
this size examined) was $16 \mathrm{~mm}$, which corresponds to $15.5-16.5$ day of pregnancy, that is 3-4 days before birth ( $\mathrm{R} \mathrm{u} \mathrm{g} \mathrm{h,} \mathrm{1968;} \mathrm{Theile} \mathrm{r,} \mathrm{1972).}$ All females (170) in which the embryo was larger than $16 \mathrm{~mm}$, were correctly considered pregnant, on the basis of visual assessment. This means that practically speaking examination of females 3-4 days before they give birth makes it possible to evaluate all pregnancies correctly.

The perceptibility of pregnancy depends not only on the size of the embryo but also on the number of them: the more embryos there are the more obvious the pregnancy. Only 26 females out of the 691 pregnant individuals examined were found to have only one embryo.

On the basis of the above arguments it was considered that inspections of females every 3-4 days makes it possible to record almost all pregnancies.

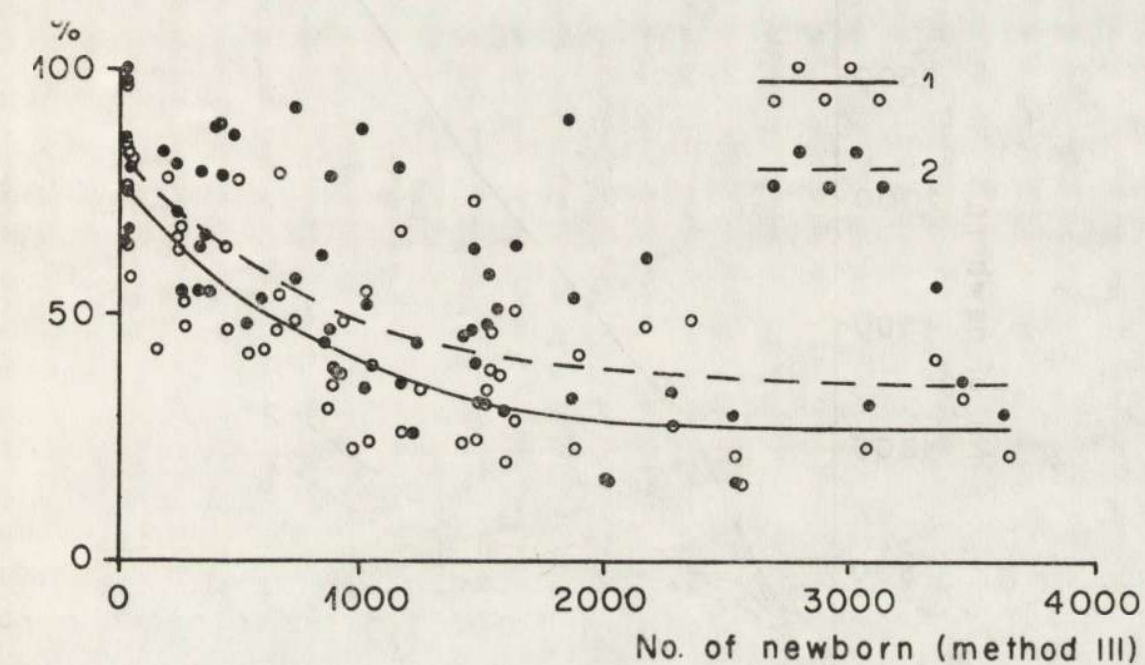

Fig. 5. Percentage of number of newborn mice obtained by methods I and II in relation to the estimate obtained by method III. Number of newborn mice estimated by method III taken as $100 \%$.

(1) Percentage of newborn mice estimated by daily recordings (method I) in relation to estimate obtained by multiplying number of pregnancies by average litter size (method III).

(2) Percentage of number of newborn mice obtained by increasing method I estimate by the number of newborn mice dying before being registered (method II) in relation to estimates obtained by method III.

Inspections made as frequently as this (twice a week) were carried out on 15 populations, and the material was also analysed for these populations as if inspections had been made every two weeks. It was found that inspections made once every two weeks underestimated the values, revealing $81.3 \pm 2.7 \%$ of pregnancies. 
Pregnancy may not end in birth, as all the embryos may be resorbed, but dissections made of 691 pregnant females revealed that resorption occured in only 5 of them $(0.7 \%)$ that is, there is only a slight possibility of the value being overestimated.

The average size of a litter calculated for females from all populations was $7.5 \pm 0.2$ individuals. This value may be an overestimate because it includes embryos estimated as live, but which might have been resorbed before birth. Analysis of the number of resorbed embryos found by

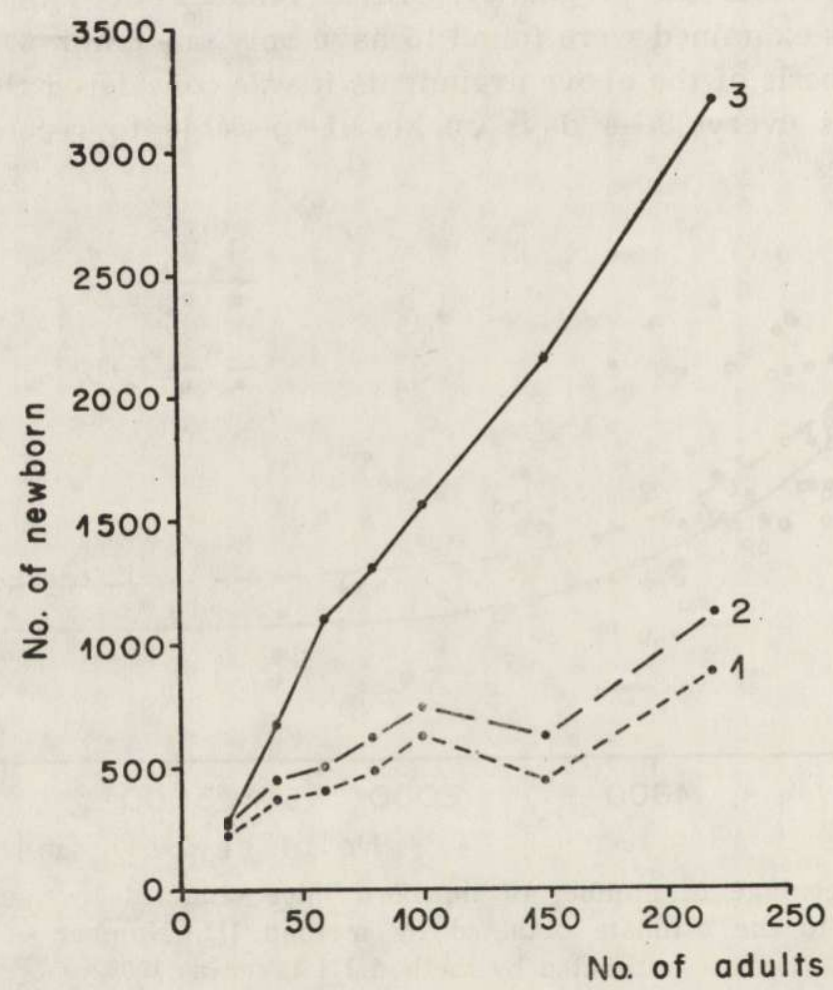

Fig. 6. Population numbers and number of mice born assessed in three ways: (1) daily recordings of newborn mice (method I), (2) increasing the estimate obtained by method I by the estimated number of newborn mice dying before being recorded (method II), (3) multiplying the number of pregnancies by average litter size (method III).

dissection shows that maximum number was $10 \%$ of all embryos and the average was only $5.8^{\%} \%$.

In populations in which pregnancy estimates were made twice a week, the number of mice born was obtained by multiplying the number of pregnancies ending in birth by the average litter size. In the other 
populations in which inspections were made every two weeks the estimated number of pregnancies arrived at on the basis of such inspections was increased by $19 \%$ (that is by the percentage by which we underestimated the estimated number of pregnancies with this frequency of inspection in relation to inspections made twice weekly) and then the values obtained were multiplied by the average litter size (third method). Estimates of the number of newborn mice obtained in this way are far higher than the results obtained by the other two methods, as is shown by the percentage of the number of newborn mice in the various populations assessed by the first two methods, in relation to the third (Fig. 5). The data given in Fig. 5 also show that the percentages analyzed decreased with an increase in the number of newborn mice estimated by the third method and therefore the divergence between these estimates increases to a value of about 2000 young, after which this percentage (and also the divergence in the estimate) is maintained on a constant level.

The numbers of newborn mice estimated by each of the three methods for populations of different sizes are shown in Fig. 6. The estimates resulting from daily recordings are several times smaller than those obtained on the basis of the number of pregnancies and the average litter size, and the divergences between estimates increases with an increase in population size.

\section{DISCUSSION}

Estimates of the number of animals born on the basis of direct counts at regular intervals, give a picture which approximates to the real one only under certain ecological conditions; for instance, when the number of adult animals is low. Under such conditions mortality amongst young individuals is low (Fig. 3) and the chance of recording them from daily observations is high. Under other circumstances the figures obtained from daily inspections may be grossly unaccurate since the mortality amongst newborn mice increases disproportionately as ecological conditions deteriorate. This method cannot be recommended in productivity studies or studies on variations in population birth rate.

Allowing a correction for mortality and assuming that it has a constant value, a greater number of mice born is obtained than by daily counting. This number is also inadequate under actual conditions.

Survival of the young is the main regulating factor in enclosed populations of white mice ( $\mathrm{W} \mathrm{alkow} \mathrm{a,1971).} \mathrm{It} \mathrm{was} \mathrm{found} \mathrm{in} \mathrm{the} \mathrm{pre-}$ sent study that there is a very high mortality rate among newborn mice. This may also be included in the mechanism regulating population numbers and may vary greatly during the population's lifetime. This 
makes reliable assessments of this mortality for a longer study period very difficult, on account of the disturbances which may ensue as the result of increasing the frequency of recording newborn mice, not to mention the amount of work involved. An estimate based on the average litter size and number of pregnancies ending in birth provides the most reliable evaluation of the number of mice born in a population.

It can be seen from the above arguments and discussion that in studies aimed at estimating the number of mice born the researcher should concentrate his efforts on estimating the number on the basis of an analysis of pregnancy records for females and average litter size, and not on attempting to make direct detailed recordings of births.

Acknowledgements: The authors wish to express their thanks to $\mathrm{Mr} \mathrm{T}$. D. He aling of Royal Holloway College, University of London for revising the English text.

\section{REFERENCES}

1. Beilharz R. G., 1968: Effect of stimuli associated with the male on litter size in mice. Aust. J. Biol. Sci., 21: 583-585.

2. Crowcroft P. \& Rowe F. P., 1957: The growth of confined colonies of the wild house mouse (Mus musculus L.). Proc. zool. Soc. London, 129: 359-370.

3. Crowcroft P. \& Rowe F. P., 1957: The growth of confined colonies of the wild house mouse (Mus musculus L.): the effect of dispersal on female fecundity. Proc. zool. Soc. London, 131: 357-365.

4. Christian J. J., 1956: Adrenal and reproductive responses to population size in mice from freely growing population. Ecology, 37: 258-273.

5. Louch C. D., 1956: Adrenocortical activity in relation to the density and dynamics of three confined populations of Microtus pensylvanicus. Ecology, 37: $701-713$.

6. Loyd J. A. \& Christian J. J., 1969: Reproductive activity of individual females in three experimental freely growing populations of house mice (Mus musculus). J. Mamm., 50: 49-59.

7. Myrcha A., Ryszkowski L. \& Walkowa W., 1969: Bioenergetics of pregnancy and lactation in white mouse. Acta theriol., 14, 12: 161-166.

8. Petrusewicz K., 1957: Investigation of experimentally induced population growth. Ekol. pol. A, 5, 9: 282-309.

9. Petrusewicz K., 1960: Some regularities in male and female numerical dynamic in mice populations. Acta theriol., 4, 8: 103-137.

10. Petrusewicz K., 1963: Population growth induced by disturbance in the ecological structure of the poulation. Ekol. Pol. A, 11, 3: 87-125.

11. S o uthwick C. H., 1955a: Regulatory mechanisms of house mouse populations: social behaviour affecting litter survival. Ecology, 36: 627-634.

12. Southwick C. H., 1955b: The population dynamics of confined house mice supplied with unlimited food. Ecology, 36: 212-225.

13. $\mathrm{R}$ u g h R., 1968: The mouse. Its reproduction and development. Burgess: $1-430$. Minneapolis. 
14. Strecker R. L. \& Emlen J. T. Jr., 1953: Regulatory mechanisms in house mouse populations: the effect of limited food supply on a confined population. Ecology, 34: 375-385.

15. Vessey S., 1967: Effect of chlorpromazine on aggression in laboratory populations of wild house mice. Ecology, 48: $367-376$.

16. Theiler K., 1972: The house mouse. Development and normal stages from fertilization to 4 weeks of age. Springer: $1-168$. Berlin.

17. Wa lk owa W. \& Petrusewicz K., 1967: Net production of confined mouse populations. [in: „Secondary productivity of terrestrial ecosystems«, ed. K. Petrusewicz]. 1: 335-347. Polish Sci. Publ., Warszawa-Kraków.

18. W a l k owa W., 1971: The effect of exploitation on the productivity of laboratory mouse populations. Acta theriol., 16, 19: 295-328.

Accepted, March 2, 1974.

Institute of Ecology,

Polish Academy of Sciences,

Dziekanów, 05-150 Łomianki, Poland.

\section{Krystyna ADAMCZYK i Wiera WALKOWA}

\section{OCENA LICZBY NOWORODKOW W ZAMKNIĘTYĄH POPULACJACH MYSZY LABORATORYJNYCH}

\section{Streszczenie}

Badania przeprowadzono w 83 populacjach myszy laboratoryjnych hodowanych $\mathrm{w}$ drewnianych klatkach $\mathrm{w}$ ciągu pięciu miesięcy. Populacje te założono $\mathrm{w}$ gradiencie liczby osobników od 20 do 220 . Wodę i pokarm podawano w nadmiarze. Dla każdej populacji oceniono liczbę noworodków trzema sposobami przez:

1) Zsumowanie liczby noworodków zarejestrowanych w kolejnych dniach;

2) Uzupełnienie uzyskanej liczby noworodków o szacowaną liczbę osobników padłych od momentu urodzenia od pierwszej rejestracji;

3) Przemnożenie liczby ciąż zakończonych porodem razy średnia wielkość miotu. Trzeci sposób daje najbardziej wiarygodną ocenę liczby noworodków. Pozostałe dwa wyraźnie tą liczbę zaniżają (Ryc. 5) szczególnie w populacji najbardziej licznych, w których znaczna część noworodków jest zjadana (Tab. 1). Wiarygodność tej metody zależy od dokładności oceny ciąży. Rejestracja ciąż przeprowadzona dwa razy w tygodniu umożliwia zaobserwowanie wszystkich ciąż. Rejestracje takie dokonywane co dwa tygodnie wykazują $81.3 \pm 2.7 \%$ ciąż. Srednia wielkość miotu uzysskana na podstawie sekcji 891 samic ciężarnych wynosiła $7.5 \pm 0.2$ osobnika. 